\title{
THE AFRICAN FAMILY IN DEVELOPMENT CRISIS IN THE SECOND MILLENNIUM
}

\author{
A.B.C. Ocholla-Ayayo \\ Population Studies and Research Institute, \\ University of Nairobi \\ P.O. Box 30197 Nairobi, Kenya
}

\section{INTRODUCTION}

Whe family is the basic social order in the society, the unit in which traditional norms and values, beliefs and knowledge, and practical skills are first imparted to the young members of the society for their future survival. It is at the family level that the language of communication is imparted to the young members without which there can be no effective chances of becoming functional adults. The family is the basic economic unit which maintains production, distribution and consumption for the survival chances of the infants and children, old and disabled adults. The language necessary for implanting norms and values, beliefs and knowledge and practical skills begins first at the family unit. The family is also the socio-biological unit that ensures orderly reproductive continuity of the human race.

\section{The African Situation}

The African family is experiencing stresses and strains, shortages and difficulties with all practical problems of social change, and deserves more practical attention and solutions. In Africa, it is at the family level that the society feels more acutely the pain of change and underdevelopment. It is the family which suffers from poor housing conditions, poor health services, shortage of food, lack of clean water and sanitation; it suffers nutritional deficiency, unemployment, and poor living conditions. The African family suffers longest during wars and national disasters, displacement and epidemics. Among the examples are Angola, Rwanda, Sudan, and Somali. The African family has a high dependency ratio, and only a few members of the family who are working have the whole burden of the unemployed, infants and children as well as disabled and the old adults; examples can be found in all African countries (Ocholla-Ayayo 1985, 1991, 1997; Ominde 1981, 1985). This state of affairs is found throughout Africa.

The question whose answer one would like to know is what was the function of culture in traditional society that may be remembered as the "golden age"? Culture in traditional societies had six basic functions 
common to all human societies. Culture is associated with sustainable development (Ocholla-Ayayo, 1980, 1997) whose functions are:-

(1) aiming at maintaining biological continuity of members of the society; by implanting norms and values, beliefs and knowledge of marriage and family institutions. They outline rules, norms and values of heterosexual relations and define people who are not permitted to enter in marital relationship and when heterosexual relations are permitted and have children. Culture provides ethics of custom whose norms and values, beliefs and practical skills are outlined in marriage and family life;

(2) aiming at educating and socialising young members into functional adults, by implanting norms and values, knowledge and skills as well as ideologies and social philosophy to enable them to become functional adults;

(3) aiming at defining and maintaining normative ethics and moral principles, law and order, by establishing social control mechanisms for regulating interactions and established relationships among members of the family and the society at large;

(4) describing the meaning of life, and maintaining practices necessary for realising causes of human suffering and remedies to them and what will happen to humanity, by establishing the mechanisms of security of survival, religious philosophy for maintaining human hope for immediate and future life and survival chances;

(5) meant for organising productions, distributions and consumption as well as providing services necessary for social life by organising norms and values for division of labour, knowledge, skills and tools for exploiting natural resources;

(6) meant to organise human population in their respective geographical locations into functional groups for their own survival by providing them with language required for communication and instruments for interactions, transfer of knowledge, skills, norms, beliefs and values, and is necessary for causal reasoning found only in human culture (White 1949; Keesing 1966; Ocholla-Ayayo, 1980) and finally;

(7) cultural aspects necessary for evaluating factual and normative ethical codes of conduct for interpreting moral rights and moral wrongs among the individuals' families, social groups by providing institutions, for judging rights and wrongs, limiting their relationships and interactions (Ocholla-Ayayo, 1997). The above functions of culture are encompassing all aspects or almost major aspects of human development in any society at least in Africa which would make the family feel secure. And a deficiency at any stage of these functions of 
culture is the source of family suffering, poverty and underdevelopment. A re-examination of each of these functions of our culture in Africa shows that our cultures, do not play any effective function in achieving these goals today (Ocholla-Ayayo, 1996; 1980; 1997). Thus, the modern developments have not taken over effectively traditional function of culture.

\section{Culture Poverty}

Thus, today, African families are living in cultural poverty. Cultural poverty has been referred to as living in a condition of rudimentary cultural elements which are ineffective to exploit natural resources necessary to feed its families and growing population (Ocholla-Ayayo and Ogutu, 1986, 1987). The use of human beings as a source of energy and the traditional African hoes for food production in the 21st century is an example. It also refers to lack of development ideologies necessary for fostering unity, common goals, the ideal of good life and security for survival and for bridging the gap between traditional and modern technological development. Cultural poverty also refers to lack of a strong democratic system necessary for reinforcing unity and promoting rapid social change. Democracy is a new concept whose ideologies are foreign just as communism. Cultural poverty also means lack of strong normative institutions as the basis for development. Society which changes from left to right, aping on other cultural values, beliefs and ethics of customs suffers from cultural " poverty (Osaga Odak, 1989, 1992). It is a cultural development gap, for example, to ask the farmers to intensify agricultural productivity using African traditional, cultural implements such as the hoe and panga, while turning a blind eye to the function of culture in development (Ocholla-Ayayo 1980; 1997). Culture is learnt, borrowed, accumulated and transmitted from one generation to another (Navoll and Cohen 1970; Mead, 1955; Kluckhohn 1945, 1948; Kroeber and Kluckhohn, 1952; Keesing 1966; Hammond, 1966). It is now common knowledge that culture can be the source of poverty, if it remained stagnant or static for so long (Ocholla-Ayayo, 1997). Culture has the propensity to resist change, or it may also promote development, if it is adapted as the basis of development.

\section{Political Poverty}

The African family is suffering because of political poverty which is a condition of being without common political ideologies, a political philosophy which could forge the unity of differing ethnic groups. Democracy, as a political ideology, is grounded in ethics of custom of other 
nations. Political poverty is the lack of common cultural values, norms, beliefs and background practices of democracy; lack of adequate social philosophy of democracy within the context of ethnicity Africa finds itself. Political poverty is often reflected in Africa in expressions such as "it is our time to rule this country", "we are being finished or sidelined", "our land is being grabbed", "I will make sure that my people also eat when I am in power" (Ocholla-Ayayo, 1996, 1997; Odak 1988, 1995; Anyang Nyongo 1993; Moi 1996). These are elements of poverty-contributing mechanisms, because they discourage inter-ethnic cooperation and unity necessary for achieving common goals of development.

\section{Agricultural Poverty}

The African family also suffers from agricultural poverty. Agricultural poverty has been referred to by Ocholla-Ayayo (1997) as the condition of continuous poor harvesting or being without modern equipment necessary for high agricultural production. It has also been referred to as the state of lack of human resources required to adopt and utilize modern agricultural technology. It includes lack of ability to use even ancient methods of production. It is a state of helplessness when it depends on natural rain water for survival, a state where human beings are no better than animals; both simply wait for rain and do nothing to make water available for both crops and human utility. They suffer from the inability to produce even fertilizers, a state of dependency on import of farm equipments, fertilizers, and sale of farm produce. A state by which the family has no power or voice to decide the price of their own commodities. Agriculture is better observed in the African family settlement patterns which totally reduce agricultural land for food and-cash crop production. It is common to see homesteads scattered all over the agricultural fertile land which could have been used for agricultural production (Ocholla-Ayayo, 1996, 1997, 1985).

\section{Urban Poverty}

African families are migrating to urban areas, hoping to find salvation there. Urban poverty is referred to as a collection of a large mass of people in urban centres producing nothing; most of them unemployed but are all waiting to eat somewhere, find someone to shelter them, and go somewhere for health care when they are ill. They live in slum quarters under appalling conditions, many eat left-overs. Urban poverty is shown in the inability of the urban dwellers to provide the necessary services required for urban families. It is inability to eradicate slums, inability to utilize appropriately and effectively the available resources; inability to mobilize the urban population to achieve a desired goal. It is also right to say that it 
is inability to eradicate corruption which has been cited as the main cause of Africa's poverty (World Bank, 1985; Anyang Nyongo, 1996).

$A$ high infant and child mortality rate is often used as an indicator of poverty in a given society (WHO, 1996; UNICEF 1987, 1996). Poverty ir Africa is a complex matter which the family as mere basic social unit canno eradicate. Among the major sources of poverty in the African family are th: inability to adopt technological innovations and the inability to utilize humar resources whereas, the African family has the ability to reproduce arr double its population rapidly (Senyonga 1975; Ocholla-Ayayo 1982, 1985). African families assert that a high number of children was necessary for the collective survival, for inter-generational economic systems and for generational continuity. Why have they not used the numerous children they produce for collective survival? Children are still important in the domestic labour force and their school attendance in the absence of substitutes constitutes a form of production deficiency. Caldwell referred to this as "reduction of wealthflow due to introduction of universal mass school enrolment of children which reduced the immediate value of children in the family production" (Caldwell 1982, 1995).

\section{High Population Growth as a Source of Poverty}

It has come to be realised and accepted by all or most African governments that high population growth in the light of low economic growth can be a serious source of poverty to a nation. In all types of development, planning requires data on the age and sex distribution of population in five-year age groups for each sex is sufficient.

i. The pre-school age population - a population aged $0-5$. This population consumes without producing.

ii. The school-age population, a population aged $5-14$ years. This population spends most of the time at school and only consumes without producing, and when out of school they are unemployed and continue to consume without producing.

iii. The youth population - population aged 15-24, today, this population unless they are school drop-outs, or have just completed their secondary schooling are part of the unemployed labour force. So they also consume without producing.

iv. The working group population, those aged 15-64, again: How many are really employed? In Africa where unemployment is over fifty percent of the working ages population, a large percent of this working group do consume without producing. 
v. The old age population, population aged 65 and over, are a population most of whom do consume without producing, and if at all they do, it must be very little.

vi. Female population in reproductive age, as population aged 15-49, who spend most of their reproductive years bearing children at short intervals and getting physically exhausted; yet they are the ones carrying out most domestic jobs and agricultural production using traditional hoes and pangas.

The above outlined categories of the African population are expressed in terms of dependency ratios; which in the whole of Africa stand at 88.6 per 100 ; and age $0-14$ is 82.9 per 100 and age $65+$ is 6.0 per 100 (WPP, 1996:368).

\section{Dependency, a Source of Poverty}

In Africa, the families which are trying to increase their saving and investment are the one burdened with the highest dependency ratios. The poor African countries have high fertility which creates a heavy dependency load for families. This makes it difficult for such families to improve their living conditions. They spend all the money they earn on food, school fees, heath care, funerals, housing, clothing, with nothing to invest or use to improve their living conditions. In conclusion, we can say that, in the absence of major economic growth, one of the major causes of poverty among the African families is high dependency ratios (Henin, 1981; Ominde 1984, 1985; Ocholla-Ayayo, 1997). There are three population manifestations upon economic growth which if not watched closely may cause poverty to a country within a short span of time, they are (a) population size, and doubling time, (b) its growth rate, and (c) its age distribution (Henin, 1981, Bogue 1959; Hyrenius 1959; Ominde, 1984; Farooq 1985).

\section{Modernization as a Source of Poverty}

Modernization can be a source of poverty because it can affect population growth through one or more of the three determinants of population growth, namely births, deaths and migration. Migration is an important factor of economic growth - its impact and the effect upon the countries of origin and destinations are well known (Oucho, 1986, 1995, 1997; Afolayan 1998; Nnoli 1998; Adepoju, 1996). Modernization has forced farmers to shift productivity priorities, for example, many farmers in Kenya have shifted from food-crop production to cash-crop production, thereby causing serious food shortages to the families. Death rates are high 
as a consequence of poor diets, poor sanitation and the absence of effective, preventive and curative medical practices (Whitehead 1994; Safilios-Ruthschild 1994; Adepoju, 1994; Ocholla-Ayayo, 1997). Family poverty in a country is dependent upon (a) how much labour capital and natural (land) and human resources (professional and skilled) are employed in production; (b) how efficiently and effectively they are used; (c) how distribution and consumption are organised; and (d) soil and rainfall types and patterns in that region, respectively. Although the level of poverty is very often measured by the infant and child mortality rates (UN 1996; WHO, 1992; UNICEF, 1996), this in turn is measured by many other factors such as level of maternal education, malnutrition, availability of clean water, sanitation facilities, health care and medical services as well as adequate shelters, among others. But what Ocholla-Ayayo $(1996,1997)$ is stressing upon is that mobility as inability to provide these basic needs is the cause of poverty in Africa (Ibid. 1997). The question I want to put for further discussion here is: Is this inability vested in the African family or is it vested in the African culture because it has refused or is resisting change?

\section{Propensity of Culture}

Since an African man or woman is definable in terms of his/her family, clan, tribe and culture, as an individual his/her personality is a consequence of learning, training and socialising in a particular socio-cultural milieu (Kesing 1966:16). It is, therefore proper to start not from his/her power to resist change, but from the propensity of his/her culture to resist change. Ocholla-Ayayo and Ogutu (1986) developed a proposition on propensity of culture to resist change. One of those human obstacles likely to hinder or slow down rural transformation (in Africa) is based on the proposition that:

"Belief systems and ethical prescriptions once established by a given population in a given environment tend to generate customs and traditions, habits and prejudices, loyalties and allegiances as well as practices that can drastically affect efforts to transform this potentially rich rural land. These belief systems and value systems as well as ethical prescriptions once established have a strong propensity to resit change. Thus, within a given environment such as Kano/Nyakach plains in Kenya, traditional values and beliefs of a people tend to remain a constant or change only slowly and therefore, it is possible to analyse their impact on socio-economic development of a rural environment such as Kano plains where a number of agricultural schemes and other development projects are being initiated"

(Ocholla-Ayayo and Ogutu G.E.M., 1986:5). 
Today, we know that between 75 to $80 \%$ of HIVIAIDS in sub-saharan Africa is transmitted through heterosexual relations, but heterosexual relationship is the main subject matter of socio-cultural ideologies of marriage and family life. Thus, although the sexual drive is primarily determined by psycho-biological processes, it is also affected, regulated, modified and even promoted by socio-cultural ideologies, ethics of customs, traditions, religious moral rules, laws, prevailing in any cultural group or society (Ocholla-Ayayo, 1989, 1993, 1996, 1997, 1998; Caldwell, 1989; Miller and Rockwell 1988; AIDSCAP, 1996; Ndiati and Kiai 1996; AIDS in Kenya 1996, 1998). Could there be no way of changing cultural practices in the light of the disaster of HIVIAIDS pandemic which is dependent on the nature of the prevailing cultural factors, such as levirates, polygyny, circumcision, cleansing, initiations, child marriage, old age marriage, woman-woman marriage, divorce and remarriage, etc (Ocholla-Ayayo, 1998/90, 1996, 1997)?

\section{Culture and Adolescents}

In the past, the traditional culture provided us with institutions for child up-bringing - such as norms and values-implanting. Today, we have no such institutions because of social change, and there is no culture policy to implement or sustain such an institution. African families are in a state of confusion. Parents say, for example, that morality and sexual education should be taught by teachers in schools, while teachers say that it should be the responsibility of the parents; whereas some religious organisations preach "no sex education at all". At the end, today children are passing the age of norm and value implanting: they are missing the rules and moral rules which make a human being a cultural being, distinct from other animals (Ocholla-Ayayo, 1980, 1996, 1997, 1988, 1991; Keesing, 1966; Krober, 1973). This is because the family as the basic social order summarising the functions of a society had some of its functions removed by social change (Wallensteen 1973) leaving gaps.

\section{Family and Funeral Ceremonies}

More often than never, the African family experiences birth, death and funeral ceremonies, more than others. Funeral sacrifices and ceremonies create unprecedented conditions that are contrary to the principle of development, production, distribution, consumption and saving. It is an African religious practice in which a large number of people comprised of consanguinal kins and affinal relatives in the kinship network plus friends and neighbours or clan members as well as curious on-lookers come to witness the send off of the deceased member of their community. In Kenya, 
among some ethnic groups, such as the Luhya, the Luo, the Teso, Abasuba, etc., this is the centre of religiousity (Ocholla-Ayayo, 1970, 1976, 1980; Egil, 1974; Evans-Fritchard 1948/50). All the above categories of people come not only to say farewell to their departed beloved ones, but also expect to be fed for the period they are at the funeral. It has so often happened that after the funeral, the bereaved family's savings have been used up within one week of death, children are left without school fees, no transport, no food, without money and sometimes a fund-raising has to be conducted to support the family (Ocholla-Ayayo, 1992:1-26). All these are done in the name of culture! Are these not enough reason for a culture to change? But why can it not be simply changed at will?

\section{Culture and Malnutrition}

The extent to which beliefs and traditional practices explain children's diseases and causes of death pose special problems to health planners in rural Africa, especially to the nations where the government has no culture policies and women's educational level is low. To uneducated family, the protein-energy malnutrition is never recognised by many mothers from traditional beliefs and practices. To the semi-literate family, the symptoms of malnutrition are not perceived as having any causal connection with infant feeding practices. From the description such as marasmus or kwashiorkor, one can find that it is believed that their attacks are due to the transgression of some forbidden traditional moral code or witchcraft and sorcery (Ocholla-Ayayo, 1976, 1991; Cosminsky 1985 and others). Here again there is enough ground for culture policy to eradicate ignorance and unscientific traditional beliefs - positive culture must be taught, learnt and accumulated when there is a sound culture policy.

Marriage and family life is again two concepts in one which are at the centre of culture in Africa as is in most societies. Today, there are many forms and types of marriages currently prevailing in Africa, especially in Kenya as a result of the breakdown of the marriage and family institutions in our society today. Whatever may be the form of marriage, legal or illegal, once a child is born in that form of union, it is unethical to call that child illegitimate or dismiss it cheaply. But that happens very often. To-date, there are child marriages, trial marriage families, child-husband families, woman-woman marriage families, polygynous unions families, serial polygyny families and many more, all of which have some social problems not readily solved with the social development taking place. In most of these forms and types of marriages, bridewealth is still demanded as culture dictates. But much has been said about bridewealth, some regard it 
as "marriage payment" or as compensation given by the bridegroom to the bride's kin for the loss of their daughter's labour contribution she would have continued to provide, if she did not leave the parents' household. Others consider marriage "payment" to be of considerable value in the sense that it is commonly used to replace the daughter by obtaining a wife for some other member of the family, usually, a brother of the woman that has been lost. Others look at bridewealth as exchange or sale of a daughter. While others consider that bridewealth should be considered a little more serious than that, because through the bridewealth a degree of marriage stability is obtained, that bridewealth establishes kinship and affinal relationships. These are demonstrated in the fact that, without a bridewealth, when a wife dies her parents and kin have the customary rights to take back her body for burial in her clan land (Ocholla-Ayayo 1989; Obudho and Aduwo, Oruka 1989; Wanjala 1989). Without bridewealth the deceased woman's children are also taken away back to her parents' household or kin. But should there be even one cow or a goat in the name of bridewealth, her husband or her husband's kin retains the body and all the children. This is still practised. (Ocholla-Ayayo, 1970, 1976, 1989, 1996; Kilbride 1990, 1997; Muganzi et al, 1987; Ocholla-Ayayo and Ogutu, 1986).

Marriage is important as the creation of the family and the basic social order. It was the hub of an African morality. It was also here that the African rituals began and ideology of life as it is lived practised. The ritual relating to the children, livestock, crop production, fishing, and even the lineage structure depended on the family unit, and the clan, so was the layout of the covert rules that were intended to govern individuals. Sexual 'behaviour, for example, began here. The concepts of incest, and illegitimacy were all spelt out from marriage and family life. Marriage based on well founded socio-cultural ideologies and philosophy is a solid foundation of the basic social order. There is no closer discipline that can do that than culture and anthropologists (Pospisil, 1970; Nordenstan, 1969; Mbiti, 1969; Ocholla-Ayayo, 1970, 1976). The rites of birth and childhood that introduce the child into the corporate community, where it will be taken care of for many years to come are only the introduction of child upbringing. Today, the family is aware that the process of child upbringing that could cultivate a child's growth into a moral adulthood by implanting physical, social, religious, cultural and economic values as well as skills to make him/her become a functional adult has been taken away by adopting other cultural and socio-economic values in the name of social change. 


\section{CHANGING AFRICAN FAMILIES}

The household in Africa is what in European and American societies would be called "family". T're household is the smallest unit of the family which either consists of parents and children and sometime the grandparents (Mbiti 1969) or it may consist of husband(s) and co-wives and half-brothers, half-sisters and grandparents (Ocholla-Ayayo, 1980). Sometimes, this form of family in which a man has two or more wives, has been regarded as having many households, erected within the same compound where the other wives and their househoids live (Mbiti 1969; Ocholla-Ayayo 1997). This is still a very common family structure in many parts of Africa, but such a structural arrangement is not practical in the urban setting, where households may be situated in different parts of town (Ocholla-Ayayo, 1997, 1991). Another category of structure, is the instance where some family households are in urban areas while others are in rural areas. This category of the family is a new one, brought about by modern industrial and market economic necessities where men and other family members are compelled to live and work in urban areas, whereas others live and perform agricultural and other economic activities in the rural villages.

In a more traditional set up, it was the man who was head of the family, never a woman, at least in the patrilineal system. Today, many family households are led and represented by the female heads. One would suggest that the patrilineal system is changing to a matrilineal one. Thus, the phenomenon of many single mothers heading large households is accepted as normal. The radical change that began in the second half of the nineteenth century and swiftly gained momentum towards the middle of the twentieth century up to the end has created another movement of change called democratization and gender sensitivity, meaning women's supremacy. These changes are total and involve not only the family, but the entire existence of African peoples making an impact upon religious freedom, market economy, political democracy, and social life, expressed in terms of gender equality and human rights.

\section{Religion and development values}

African people are deeply religious and experience these changes in religious terms. Hence, the resistance to some of those development imperatives which are translated in terms of religion, for example fertility control and the use of contraception and resettlement schemes, (OchollaAyayo 1985; 1997). The modern development has caught Africa with many: arms, almost beyond human control; no people or country can remain unaffected. African families must now learn, accumulate and adopt the new 
culture, the culture of science and technology with modern communication and learn to live in cities and towns. Families are being divided, forced to live apart in order to labour for their survival and must accept new life styles or perish (Achebe 1958). Christianity from Western Europe and North America came to Africa not simply carrying the gospel of the New Testament but as a complex phenomenon made up of western culture, politics, science, technology, medicine, schools and new methods of conquering nature which African families must adopt effectively if they want to survive (Hunter 1962; Southall and Gutkind, 1956; Herskovits 1962; Ocholla-Ayayo, 1991, 1997). Young members of African families, both female and male, must assimilate not only new religions, but more so, science, politics, technology and the market economy (Ocholla-Ayayo, 1997), yet they seem to be more obsessed with religious salvation than seeking science and technological development.

It is the young people who are becoming more and more detached from their ethnic group roots. Those attending schools and working in the urban centres and towns, bring back modern innovations and "all that glitters" to the rural populations. Although they have become the vehicles carrying the new changes and introducing them to their families and villages, their families and villagers have discovered that they cannot produce what they have learnt! Today, the rural population are crying out for medical care, both preventive and curative - there is none; HIVIAIDS has began to kill them in large numbers - there is no care. Infant and child mortality has began to rise; all sorts of diseases such as TB, yellow fever, malaria and cholera that were once major killers in Africa are back. In most parts of Africa, better health care which resulted in increased population has deteriorated rapidly. High population growth rates have began to breed maniy social problems in the light of African economic development inabilities (Henin 1981; Ominde et al, 1983; Ocholla-Ayayo, 1997).

\section{Detribalization?}

It is not the first historical change that took place. The first was colonization in which Africa was partitioned into many sectors; the French; the British; the Portuguese/Spanish, and the German sectors. Then, came decolonization, democratization before achieving modernization. We can see the elements which remained unchanged in the level of decolonized and modernization stages, as the French language, English language, Portuguese or Spanish language, and of course their culture remained undecolorized and unmodernized. There came another movement called detribalization. These changes which affected all spheres of life, have been termed "detribalization" on the grounds that the traditional lifestyle is being 
so deeply undermined that tribal identities are fading away as other identities make claims on the individual and the community (Mbiti, 1969). But again if one looks at Africa in the 1990s, or even upto the end of the $21^{\text {st }}$ century, one sees a more complex picture in which tribal identities survive. We still refer to traditional socio-cultural beliefs and values, norms and practices which hinder African development. They are infecting political life, economic development, and found in agricultural production and technology. Although it is the family which is most severely affected by change, it is within one family of household that we find two totally different worlds co-existing: the children that may have attended colleges, and universities and have built brick and tile houses while the parents remain illiterate or semi-illiterate and keep on cultivating their field with hoes or wooden sticks, living in their round conical grass thatched huts "the tukul" or at best living in "kibanda" houses. In such a family, there are two sets of expectations, economic standards, cultural concerns, and world views (Van den Berght, 1965; Rees, 1959; Mbiti, 1969) and which Ocholla-Ayayo (1997) called untransformed or those experiencing inverse transformation. These changes show outwardly in many ways such as education for both sexes, styles of clothing, housing, food, means of transport and moral behaviour, inwardly in many, they show themselves as socio-cultural beliefs and values, norms and practices which are regarded as detrimental to development (Ocholla-Ayayo and Ogutu, 1986; Ocholla-Ayayo, 1997. 1998).

\section{Modernization and its consequences}

After the detribalization process failed to achieve complete change, a new concept was found called modernization. In the final analysis, it is the family and the individuals within it who really feel the change - experience it, accept or reject it, and hasten or slow it down, modify or adopt it in full. Modern change has brought many families and individuals in Africa into situations entirely unknown in traditional lifestyles. Some are forced directly or indirectly to practise prostitution or work in mines, tea plantations, factories or European, government style farms or houses, etc., leaving their land, families and relatives behind. Sudden detachment from the land and family - to which Africans were mystically bound - and being thrust into situations where corporate existence has no meaning have meant that individuals are served, cut off, and pulled out of the context of corporate morality, customs and traditional solidarity (Mbiti 1969; Ocholla-Ayayo, 197.6, 1991; Van den Berghl, 1965; Rees 1959; UNESCO, 1986). People lose their values and norms and have no firm footing anymore. Mbiti (1969) refers to these as people who are "uprooted but not necessarily 
transplanted" yet. They float from the rural world to the urban and back again, but they are dead to the corporate humanity of their forefathers. Lacking the moral values of the traditional set-up, their social behaviour brings them only misery and untimely death, as witnessed in the current HIVIAIDS pandemic transmitted through heterosexual relation (OchollaAyayo 1990, 1997, 1998), a process which was firmly controlled by the traditional mechanism of social control.

Today, individuals are involved in these changes and yet alienated from them; becoming alienated both from traditional ways of life and the new lifestyles brought about by modern change (Rees 1959; Southall, 1961; Mbiti, 1969; Ocholla-Ayayo, 1976, 1980, 1991, 1997). They are poised between two positions: the traditional solidarity which supplied land, customs, ethics, rites of passage, a burial place upon death, customary law, religious hopes and historical depth (ethnic identity); and modern way of life of economic activity, education, transport, communications and political debate - now called democracy which are very important for individuals but are externally controlled and manipulated (Ocholla-Ayayo and Igbozurike, 1973 and others).

The traditional life of the family, whose norms, beliefs and values are being blamed for failing many modern development projects is being "swept aside", and the further it recedes into the past the more golden it appears. African families today can neither return to the past nor expect to find much hope in the future. Families are divided into two, blaming each other for having supported change or for having not resisted it firmly enough. Thus, in the family, the father is blaming the mother for having encouraged the daughter by accepting her premarital child, to which the mother responds by saying, she is not the only one with a premarital child - how about the many around us right here, and why didn't you try to stop them?(Juma, 1989; Ocholla-Ayayo and Ogutu, 1986).

\section{Urbanization and Family Crisis}

Modernization in the urban centres has brought problems of housing, employment, earning and spending money, alcoholism, drugs, prostitution and corruption as well as the emerging new diseases such as HIVIAIDS. Unwanted children, orphans, criminals, delinquents and prisoners, all of whom need special social care, present problems beyond the family's abilities to cope. In the traditional set-up, some of these problems would have been dealt with through kinship networks, but today such networks are disintegrating, and in any case the ties of kinship do not have the same power in the city as they had in the country. Individualistic urban life demands its own code of behaviour. Emphasis has shifted from. "our" to 
"mine" from "we" of traditional corporate life to the "l" of modern individualism. Today, people say "my car", "I take my child to school", "I will go to the market" and so on. When a child falls ill, perhaps only one or two other people know about it and come to visit; when one is hungry he or she finds that begging food from a neighbour is either shameful, unrewarding or both; when bad news arrives from relatives in the countryside, a person cries alone even if hundreds of other people rub shoulders with him or her in the work place; and even when being attached in the street by robbers, the individual cries and struggles alone (Mbiti 1969; Ocholla-Ayayo, 1997). The masses around the individual and his or her family are both blind and deaf to the family's situation, indifferent to them as people; yet the solution to individual socio-economic problems is in corporate life of a kind not necessarily equivalent to traditional life, but which considers the welfare of the many and that of individual as well (lbid).

In rural Africa, the family experiences great stress and strain in this changing situation. Everywhere in Africa, families are being told to raise funds for school buildings, to pay school fees, to contribute towards health care, to pay one-tenth of their income to the church. They are taxed on every item they buy in the shop, and if they are in the towns and cities, they have to pay house rent, pay for water and electricity, and pay for sewage and trash collection. If they are workers, their salaries are below the level of subsistence. Living conditions are universally appalling. In the urban zones, families are housed in slums and crowded rooms and in the rural areas they still live in round huts of the type used by their ancestors. African families lack clean water, suffer from nutrition deficiency and have no regular means of transport. In most regions, the few health centres that exist are continuously without medicines and people must walk distances for any of these services. Famine and drought are common, conflicts and wars that displace people are frequent and widespread (Ocholla-Ayayo, 1996; 1997).

- Marriage and family instability have increased considerably under modern strains, giving rise to higher rates of divorce and separation than in traditional life. This has promoted free sexual relations which have caused the rapid spread of HIVIAIDS in Africa. Polygyny is gradually dying out in many parts of Africa, while temporary union and cohabiting is rapidly increasing in the towns and cities in Kenya.

The urban social life is conducive to the spread of HIVIAIDS. In fact research in Kenya shows that HIVIAIDS may have "began" in urban areas and quickly spread to the rural regions through urban-rural migration. Data accumulated on AIDS in Kenya research have shown that in 1993-1994 urban adult HIV prevalence was 5-7 percent while rural was between 3-4 
percent; in 1995, urban prevalence was between 13-14 percent, and rural prevalence was 6-7 percent, whereas in 1997 the urban adult HIV prevalence was 12-13 percent, while rural prevalence was 8-9 percent (AIDS in Kenya 1994, 1996, 1997 reports). The fact is, married men often must leave their wives at home in the countryside and go to work in the towns where they remain for several months or even years without going back to their families. This is coupled with the fact that many divorcees and separated women and single uninarried girls who today migrate to urban centres and cities carryout "free" sexual relations not common in the traditional life style. Prostitutes or so-called commercial sex workers can be found in every African city and town since the beginning of the 1990s, this being an economic necessity or convenience for women without decent sources of income, it helps them to earn some money, find somewhere to live and meet some of the demands of city and modern life (Ocholla-Ayayo 1989, 1990, 1997).

\section{Rural vs Urban Families}

Although rural life in Africa retains many of the social features prevalent in the pre-colonial era of about a century ago, many modern lifestyle have aiso arisen. The majority of African families continue to be oriented to an agrariari lifestyle and depend on the family labour force for subsistence foods and cash crops. Within a family, as in the past, women and children are the most important source of farm labour as well as domestic labour. For this reason large families are sill desired by both men and women and polygyny is seen as means of increasing family size and thus providing additional free labour. in a recent study of western Kenya, most families interviewed responded to the question: "what do you like most about your children?" by saying, they help alot in domestic and farm activities (Kilbride, 1990). Other studies by Jansen 1984 in Kisii and Bradley in Kakamega, South Ritanyi 1994 have also reported similar findings. Most families in rural areas still expect their children to heip with various activities (Oppong 1990s). Rural family life continues to be very much a collective enterprise, constituting an interpersonal, interdependent system within which kinship, and age and gender roles are clearly utilitarian and reciprocal (Kilbride, 1986; Ocholla-Ayayo, 1990; Obunga, 1987).

Family life in urban areas has changed much more. In the light of human rights, child rights, spelled out in the UN (1994) Charter, urban children contribute much less economically, under labour laws. Older children may heip clean the house, wash the dishes or be sent out to buy vegetables and a loaf of bread and milk, but that is about all. Urban African families tend to experience children as a burden, while rural children are still 
highly valued, serve important economic roles in the family, and are the responsibility of extended family members in situations where parents are unable to provide care. The seven roles of African children have been described by Oppong ( 1980 s) in great detail.

\section{Demographic Change and Economic Growth}

Three aspects need to be examined when considering the effects of the demographic situation in a country regarding its economic development: (a) population size, (at the basic social unit, the family size); (b) growth rate, (at the basic social unit, the family total fertility rate); and (c) age distribution (at the family level, birth spacing, age distribution within the family). These factors are closely interrelated and often difficult to separate. Their interactions and consequences are discussed below.

A favourable demographic situation at the household level can mean different things to different families. To some, it means that families can consume more; to others it means that the economy saves and invests more of its annual gross product, (which is rare in Africa even at national economy level). Still to others, it may mean more capital per worker, so that output per worker is increased, which is the essence of economic development (Henin 1981). It is not necessary to decide which of these views is the more correct, for all these manifestations of economic development are associated with higher output per capita even at the level of households units.

One of the most stubborn tendencies in popular thought about the family is to refer to families as being "small" or "large" in size. Elementary logic suggests that there must be a state in which the family has just the "right" number of children - the optimum family size. But in the present state of affairs nothing is easier than to show how impossible it is to argue that birth spacing or large family size alone is a major factor in determining family economic prosperity (Ocholla-Ayayo, 1997; Ocholla-Ayayo and Igbozurike, 1973). No matter how it is measured, density can be high and low or family size can be large or small in countries that are poor or rich, without the slightest systematic tendency.

Indeed, it is plausible that in very sparsely settled regions of Africa, a large population or a larger family size would be better able to make use of natural resources. There would be economies of scale, the division of labour would be facilitated by greater density of settlement, transportation costs would be lower, and so on. Beyond a certain point, of course, there might be diminishing returns and the advantages of a larger population or larger family size would vanish. For the time being, if the optimum family size seems larger than the actual one, it is easy to believe that population 
growth does not constitute a problem. The central flaw in such an argument is that it is vague in relation to the role of technological change and capital formation, which will displace the point of "optimum" family size (or population size) even while the actual family size (or population) is moving towards it.

If there is any relationship at all between the rate of family size change and the rate of family capital formation and technical change, then the fastest way of raising family income per head is not necessarily to increase family size. In some conditions, it may well be, but in some other conditions it may well not be, and there may be reasons to encourage it, but the entire argument breaks down if the growth in family size.competes with family capital formation. Nevertheless, most African families today live from hand to mouth and the question of capital formation is out of discussion. In other considerations, female migration and wealth dissipation (discussed by Ocholla-Ayayo, 1981/82) have serious consequences for both fertility and economic growth for those who practise patrilineal exogamous family formation. It is a system where women move from one direction and wealth moves in the opposite direction, as bride wealth exchange. By and large, however, size seems to be of subordinate importance. At a macro level, neither the present nor the future size of population constitutes a major economic problem; the real problem according to Henin (1981) is the excessive rate of population growth which impedes the progress of modernization, in the light of low economic growth.

At the micro or household level, the real problem is not only the high total fertility rates (TFRs) detrimental to economic savings and investment, but also birth spacing (which impacts upon age distribution within the family). The dependency ratio is based on the fact that every member of a society is a consumer but only some members are producers (see previous discussion in the text). Airica is a continent with a smaller proportion of its population producing goods and services while a larger proportion of its population consumes and enjoys the services being produced by the few.

\section{Dependency and Economic Development}

The burden of dependency (the ratio of persons who are in a dependent status because of their age -too young or too old to work - to persons at ages making them eligible for productive work) is relatively high in areas characterized by persistent high birth rates, and low in areas with low birth rates. The burden of dependency is, therefore, lower in contemporary Europe than in Africa. African families deviate significantly from their counterparts in Europe. First, fertility levels are certainly very much higher and indicate a long road ahead, if African families are to match 
the fertility levels prevailing among European families. The second important deviation lies in the fertility differences between regions and countries in Africa. What factors lead to such differentials?

Today, much is known of the reasons for these differences in fertility between or within countries. Various factors such as differences in levels of education, age at marriage, use of contraception and in proportions marrying have been suggested in many studies (UN, 1965; Henin 1981; PSRI 1982-1998). Such distinctions, however, could play minor or major roles in bringing about the observed differences, since available information shows that in most African countries most women are married by the age of 20 and stay in marriage life with close birth spacing throughout their reproductive age.

Another factor that has usually been suggested is the prevalence of polygyny in African families or marriages (UN, 1965; Henin 1981). Lower fertility on this count may arise from the lower average frequency of coitus among women in polygamous families depend which more heavily on coital frequericy rules than on preference. Other factors which may be important are frequency of divorce and early widowhood; the latter resulting from excessively high mortality in Africa generally. Further reductions may result from prolonged separation when husbands migrate in search of employment (UN, 1965). Prolonged lactation and taboos surrounding it likewise have an effect in many parts of Africa, though this is fading as a result of mothers taking jobs outside the home (Ocholla-Ayayo 1997; Bradley 1997; Wandibba 1997). Perhaps, one major factor is associated with women education levels. Studies in Kenya (PSPI 1983-1996) have concluded that the lower the women's education the higher the TFR, and the higher the women's education level, the lower their TFR.

\section{Family ties in the Urban Setting}

Thorough-going urbanization entails considerable socio-cultural and socio-economic autonomy from the rural way of life commonly practised by the majority of African societies in the rural areas. But the increasing number of people moving to live and work in small and secondary towns throughout Africa implies a merging of the urban ways of life with the traditional systems, in as much as these minor urban centres will be required to interface with agriculture to provide all the forms of support which may be required (Ocholla-Ayayo and Ogutu 1986; Ocholla-Ayayo, $1989,1997)$. The contract networks required for the achievement of socioeconomic goals in the new African urban-rural setting have been studied through the lens of kinship networks. Social security is the mechanism that aims to transfer financial and other economic benefits from the working 
generation to those who cannot work because of age limits, disability, or other dependency status; however, it should be linked closely to the principle of kinship ties, which provides a traditional form of social security. Despite the existence of formal, government supported social security schemes, in many African states, the aged and the young have preferred to depend on parents and certain other categories among the members of kinship groups (Ocholla-Ayayo, 1984, 1986; Obunga, 1987). In societies where the family is a tightly integrated unit, the aged would not be of concern beyond the immediate family, especially in the urban setting. Under-aged children without parents may look for guidance from a member of the kinship group who has moved to the urban areas, since there are no under-age children's home (orphans, etc) in the rural areas. This pattern is also changing because it is common to see a large number of children roaming about the street with the name of parking boys. But the fact is that, there are very few "parking girls", implies that these boys are sent by relatives or parents who should have looked after them but prefer them to beg for money while the girls are doing domestic jobs.

The effects of urbanization on the role of the extended kinship are thus fundamental to the principle of socialization and solidarity among the members of kinship units. While Wirth (1938) once contended that urbanites are characterized by secondary rather than primary intimate relationships and that the urban family, wherever it may be, is free from the large kinship group leaving members free to pursue their own interests, Ocholla-Ayayo $(1986,1989)$ and Obunga $(1987)$ have coricluded that Wirth (1938) was referring either to Euro-American families or to long-term, permanent city dwellers who have become completely cut off from any rural relationships over the passage of time. In most African countries, such a situation is only just beginning to emerge. The predominant situation, rather, is that urbanization has led to split families and to very loose kinship structures that play down the importance of relatives. Even the communal responsibility to care for one another has been eroded as emphasis has shifted to individual families.

In many African countries, including Kenya, Uganda and Tanzania, urbanization is already close to reducing kinship down to the conjugal family (parents and children). Elsewhere, many studies have been carried out which attempt to refute the idea that economic and other needs formerly met within the network are now being served solely by non-kin agencies. But Smelser (1967) has argued that even the most developed countries still show some viable extended kinship structures. Studies carried out in Kenya and elsewhere in Africa have also shown that the kin network often plays a 
positive role in residential foothold being curved out in an urban area by one individual who is followed later by another kin member.

There is also the question of kinship obligation whereby an urbanite feels obliged to relate to and assist the other kin. Such assistance is a crucial factor in binding kin relationships and in contributing to social welfare. In fact, to the adjustment-oriented urbanite, selective obligations to kin is one method that the family uses to adapt to industrialization. The urban African is dependent upon rural products. Kinship obligation is not based on the social responsibility norm, but rather upon the fact that the existing relationship is an ethical one which includes a moral obligation to provide support. Relatives are, to a great extent, "given" in the individuals social milieu; he or she does not choose them. They may be scattered or clustered, numerous or few, remote or proximate, depending on the fertility, migration and interpersonal history of previous generations (Adanis 1968).

Kinship links in the secondary towns of Africa are perhaps more intensive and more a matter of daily routine than the kind of links found in major cities. Also, in as much as these are relatively young towns, one would expect kinship loyalties to persist among the majority of their residents. But in major cities such as Nairobi or Lagos, kin networks have began to take a different pattern. Kinship networks in Khartoum, for instance, are seldom entirely dispersed but are held together only by telephone calls, letters and periodic weekend visits. Most Nairobi or Harare residents are still only first and second-generation residents of the city (Obudho, 1981); most, having been raised in rural parts of the country, still have more attachments to the rural areas than exclusive links developed within the urban area itself. Thus, it is natural for a kin web to be already firmly established within the city. Most of the kin are found in the urbanites' rural homes of origin and it is to these homes that they travel or unite to seek assistance from one another (Ocholla-Ayayo, 1986, 1989; Obunga, 1987).

In major urban centres like Nairobi, Harare, Dakar, Lagos or Addis Ababa, residents have distinct categories of interaction, which may be professional, official or business-related. Even the more social and religious ones, such as attending football matches or going to church, do not bring relationships much closer than the kind we find in kinship networks and affinal relationships. While some churches have recently began to provide some elements of moral support by coming to the aid or comfort of their members who are bereaved, the church does not take on the responsibility to support individuals' education, health expenses, marriage, bridewealth, food and other daily expenses which are associated with kinship obligations (Ocholla-Ayayo, 1989). Thus, socio-cultural obligations have much to offer, and the responsibilities of kinship cannot be easily taken over by any 
individual or an organization or even by the government. Mukras and Oucho (1986) have shown how urban-rural remittances can reaffirm kinship ties. Ocholla-Ayayo (1986, 1989) and Aloo-Obunga (1987), examining the extent of kinship dependency and the exchange of remittances, have pointed out how rural residents also transfer their agricultural products, food in particular to urban dwellers. Rural kin also secure property for urban dwellers. All these do not balance remittances to rural kin, however, and as a result the urban dweller with many rural kin cannot save and invest for further development.

\section{Kin and Affinal Dependency and Flows of Wealth}

Caldwell (1980) has argued that the prime mover behind fertility transition is mass education: "In traditional family-based production, family morality dictates that children work hard, demand little and respect the old. Wealth flows upwards and high fertility is profitable". But such a family morality cannot, according to Caldwell survive the change brought about by national education systems.

Public education is seen to:

1. increase both the direct and indirect cost of bearing children;

2. decrease the child's potential as a worker both inside and outside the home;

3. make the child - as a future producer rather than a present producer, dependent upon the household for support;

4. promote agendas, such as increasing production in a capitalist economy, that differ from the parents' values and;

5. propagate individualistic values.

Caldwell adds that where occupational-educational chains exist, older children who have been educated often hold jobs which enable (or oblige) them to send the younger children to school. The strategy for parents is then to educate the first three children, for example, and thereby reduce considerably the educational expenses for the remaining children. Caldwell did not see this as perpetuation of kinship morality, whereby older sons would be obliged to support not only their younger brothers but also other members of the extended family. Caldwell $(1989,1982)$ noted that the persistence of such kin networks lessens the impact of education on large households. Wealth will continue to follow-up words in Africa so long as kinship lineages and ties persist. Indeed, recent studies suggest that the direction of wealth-flow in urban-rural remittances continues to be upwards, that is, from children to parents for the bulk of the children's working lives and only briefly from parents to children during the latter's schooling period 
(Bradley, 1992; Mukras and Oucho 1986; Ocholla-Ayayo, 1986, 1989; Aloo-Obunga 1987).

Studies conducted in Kenya by the present author between 1986 and 1989, and by Aloo-Obunga 1987, had the following conceptual hypotheses:

1. Kinship obligation and kin dependency are normative and are likely to persist because they have a moral basis;

2. Kinship obligation and kin dependency are based on both social responsibility and the fact that kinship relations exist;

3. Urbanization has not given rise to values that have completely isolated the nuclear family from its kin, even though the kinship unit has been reduced - indeed minimized;

4. The importance of relatives has been undermined by urbanization, to the extent that communal mutual responsibility to and for each other has been eroded;

5. Kinship dependency affects the family socially and economically, since family relations have been reduced to mere money relations and appreciable rewarding.

The empirical findings of the Kenya studies were as follows:-

1. A large majority of urban dwellers in the city of Nairobi and in Migori town were found to be staying with kin or affines, whatever the nature of the dwelling;

2. Urban dwellers were found to be supporting the education of their kin or affines, regardless of their income;

3. There was no urban dweller who did not support in full or in part the education of a kin or affine;

4. Most urban dwellers have been asked for some assistance, either financial or material, from kin or affines;

5. Help in job placement is a common request from kin or affine, one which every urban dweller expects to receive;

6. A kin and affinal relative may be welcomed regardless of whether he or she brought a gift from home;

7. A kin or affinal relative may arrive regardless of invitation to come;

8. A clan member is obliged to welcome a kin or affine regardless of his or her social or economic status;

9. Kin or affines who come to stay for an extended period with relatives living in the urban area are coming to look for jobs, or are working but have no housing or school;

10. Kinship ties are important as a social and economic security; 
11. Members of the kinship group will be the most willing to collect money to transport the body of a deceased clan member, regardless of whatever financial difficulties he or she may have.

Additional findings of the Kenya studies (Ocholla-Ayayo, 1986, 1989); Obunga (1987) should be mentioned here. Some 62.2 percent of families were staying with kin or affines and supporting fully or partly the education of their relatives. Of the 2500 persons interviewed, 63 percent had been obliged to provide financial and material assistance toward the burial and funerals of relatives who had died at home or in urban centres. Some 90.7 percent had accepted responsibility, in one way or another for assisting kin or affines. Thus, compliance with such requests was quite high, an indication that respect for kinship and affinal ties was flourishing. The findings also suggest that the dependency ratio remains quite high, and that without this kind of security the unemployed and under-aged, the aged and the handicapped would simply perish. Such a high degree of compliance to kin demands further encourages kin dependence. Most of the respondents said they were under social or moral obligations to stay with relatives.

While it is evident that the respondents had not invited him to stay with them in the urban areas, moral obligations were motivated by ethics of custom (Ocholla-Ayayo, 1976; Baylis, 1958). When respondents who had come to seek help from those working in the city were asked if they had any other dependents at their rural homes or anywhere in Kenya who relied on them for their livelihood or anything else, 57.6 percent of them said they had.

Those urban dwellers who had kin staying with them but felt unobliged said it was too expensive or there were others in town with whom these relatives could stay quite comfortably, but they just preferred staying with them. The working kin felt that their income was too small to pay for rent for a reasonably decent house, feed their own family, and still have something to share with relatives coming to the city or remaining at home in the countryside. It should be noted that the dependent kin who were said to be working were either casual labourers or temporarily employed or just low paid workers.

As to whether kinship relations were regarded as intimate or important in one's total life situation, 61 percent indicated that they were and only 39 percent - mostly of the younger generation (between 20 and 29 years), maintained that they were not important, although they were being assisted by their kin, without which they could not have stayed in the city. Others were among those who have been kicked out for misconduct. The adult who maintained that it was unimportant to keep kinship relationships intimate, argued that keeping such relationships was expensive and 
cumbersome, ruined families and discouraged independence and privacy on the one hand, and led to poverty on the other. Those who said they were important gave various reasons, such as mutual benefit in time of need, companionship, consultations, harmony, unity of continuity, social security, solidarity, familyhood, upholding tradition, "who else could we go to", and the sheer fact that relatives could not easily be ignored. Many conclude by saying such things as "blood is thicker than water"; "Charity begins at home"; "If he does not help us when he can, he will not expect others to help him, say, when he is thrown out of his job"; or "who will bury him"?

Although urbanites recognized the economic strains of the extended farrily, they still held that kinship, relationships were necessary, especially in times of happiness and sorrow. Those in urban areas perhaps realize this more than anyone because in time of need, it is the kin and affines who come to one's aid. Urbanites are also aware that there is a real need for socio-economic development, but this can only be effected through saving and. investment or cooperatives. With existing kinship ties and support networks, however, this is not possible. They also felt that the persistence of the extended kinship system was one sure way of upholding the African tradition of mutual love and dependence.

African social life is built upon the principle of kinship network of distribution of consumption, but consider the level of production. The concept of 'harambee' at the household, lineage and clan levels suggests that kinship ideology and kinship systems of production, distribution and consumption are more positive than any system that could be introduced in Africa. The fact is, no government will come to support an individual or a household unit - the family - in time of need, but the kinship network can do this and has done it. In this author's view, then, the problem is how to perfect the system in the light of modernization. Even so, a positive view of the kinship support network should not obscure its disadvantages, but every thing has two sides of the coin. The view is widespread that kin are a nuisance to the urban household, especially as their presence is seen to affect the family negatively in terms of financial and material well-being. Moreover, decisions on matters relating to routine welfare (shelter, education, food, clothing, health) usually provoke very trying moments for the family.

\section{CONCLUSION}

Sacrificing for investments of all kinds always entails a degree of suffering. That is perhaps one aspect of development. One must make some saving to use as security in old age. The security that kinsmen provide at old age is what one invested in their well being. Homes for the 
hembers of one's kinship group. Thus, most people who supported a insperson in one way or the other said they felt obliged to do so. But this bligation should not be seen as merely social. It is a socio-cultural and ocio-economic obligation whose quality can only be improved by a high evel of development and modernization.

Support networks provided by extended family ties comprise stable elationships, not sporadic ones. The functions of the extended family prough kinship networks in the development of the new rural-urban atterns is an area which has yet to be adequately researched. Whether he system is disintegrating due to urbanization in Africa is still debatable ind, therefore, remains an interesting area of study. The fact that the come of one person has to be redistributed to many others who fall within inship networks ought to be of concern to government. An African worker's hcome helps to educate, clothe, provide shelter for, and feed others in ddition to his or her own immediate family. Adherence to the demands of xtended kinship therefore seems to be one way of developing one's larger amily and the community in general. To this extent, a more relaxed axation system could be one way of encouraging individuals to support thers in a newly introduced cost-sharing policy in many African countries. on the other hand, it is certainly the case that some individuals in urban entres find themselves unnecessarily overburdened by kin who would lave been enabled to become more productive in their rural homes.

Thus, development plans could take care of such anomalies by romoting the development of rural areas and the creation of jobs. Migrants nove to urban areas because of lack of facilities in the rural areas; an irban centre is viewed as a place of relief and hope, where one can receive ducational opportunities, medical services and above all employment. If ne new African rural-urban centres are to be viewed in this way, then they nust provide the opportunities and facilities badly needed by the rural iopulation.

\section{REFERENCES}

$-1993$

"Socio-Economic Aspects of sex roles and reproductive health" in UAPS Conference on Reproductive and Family Health in African 8-13 November, Dakar.

chebe, C. 1958

Things Fall Apart. London, Ibadan, Nairobi; Heinemann Educational Books.

dams, B.N. 1968

Kinship on Urban Setting, New York: Markham Publishing. depoju, A., 1977

Rationality and Fertility in the Traditional Yoruba Society, South-West Nigeria; in C. Caldwell (ed). The Persistence of High Fertility: Population Prospects in the Third World Vol.I, Canberra: Australian National University Press. 
Adepoju, A., 1984

Migration and Female Employment in South-West Nigeria; African Urban Studies, 1 (Springs).

Aderanti Adepoju (ed) 1997

Family, Population \& Development in Africa, Zed Books Ltd, London \& New Jersey.

Ajayi, A.A., and Marangu, L.T., Miller, J. and Paxman, J.M., 1991

Adolescent Sexuality and Fertility in Kenya: A Survey of Knowledge, Perceptions an

Practice; Studies in Family Planning, 22(4), July/August.

Basden, G.T., 1921

Among the Igbos of Nigeria. Philadelphia, J.B. LippinCott.

Bradley, C. 1997

"Why Fertility is Going Down in Maragoli", in African Families and the Crisis of Socia Change, 1997, ed. Weisner.

Bradley, C., 1992

Fertility and the Household Division of Labour among the Maragoli of Western Provinc

Kenya; Unpublished Paper presented at Inter-Faculty Seminar, PSRI, University of Nairobi.

Brown, R.,(ed), 1950

African Systems of Kinship and Marriage, Oxford: Oxford University Press.

Caldwell, J.C. and Caldwell, P. 1987

The Cultural Context of High Fertility in Sub-Saharan African, Population and Developmen

Review, 11, pp.29-51.

Caldwell, J.C., 1980

Mass Education as a Determinant of the Timing of Fertility Decline; Population an

Development Review 6(2), June 225-55.

Caldwell, J.C., 1982

Theory of Fertility Decline, London: Academic Press.

Caldwell, J.C., 1990

Cultural and Social factors Influencing Mortality Levels in Developing Countries; Annals o the American Academy of Political and Social Sciences, 510.

Caldwell, J.C.; Caldwell, P., and Quiggin, P., 1989

The Social Context of AIDS in Sub-Saharan Africa, Population and Development Reviev 15(2):185-234.

Dyson T., 1996

Population and Food: Global Trends and Future Prospects; Routledge, London and New York Egil, H. 1974

Luo Religion and Folklore, Oslo/Bergen: University Forlagat, Munksgaard/Copenhagen

Scandinavian University Books.

Evans-Pritchard, E.E., 1948

The Divine Kinships of the Shilluk. Cambridge: Cambridge University Press.

Goody, J. 1990

Futures of the Family in Rural Africa; in G. McNicoll and M. Cain (eds). Rural Developmen

and Population Institutions and Policy (Supplement to Population and Development Review)

New York: Oxford University Press.

Hammerslough, C.R., 1991

Women's Groups and Contraceptive use in Rural Kenya; paper presented at the IUSS Semina on the Course of Fertility Transition in Sub-Saharan Africa, Harare (Nov).

Hans-Egil Hange, 1974

Luo Religion and Folklore Universitets Forlaget, Oslo-Bergen, Tromso.

Hans-Egil, H., 1987

Marriage, Inheritance and Fertility Management Amongst the Malian Fulani in the Cultura

Roots at African Fertility Regimes, Proceedings of the Ife Conference, Ile-Ife, Nigeria.

Henin, J.K., 1983

Feeding the Cities and Feeding the Peasants: What Role for Africa's Women Farmers? Work Development 11(12). 
Henin, R, 1981

Population, Development and Economic Planning, PSRI, University of Nairobi.

Jensen An-Mag. \& Juma Mag. N., 1989

Women, Childbearing and Nutrition: A Study from Bungoma, Kenya, Norwegian Institute for Urban and Regional Research, Oslo.

Kilbride Ph. \& Kilbride J. 1997

"Stigma, Role, Overload and Delocalization among Contemporary Kenyan Women" in African Families and the Crisis of Social Change 1997, ed. by Weisner, Candice Bradley and Philip L. Kilbride.

Kilbride, P.L., 1986

Cultural Persistence and Socio-Economic Change among the Abaluyia: Some Modern

Problems in Patterns of Child Care, Journal of Eastern African Research and Development

Vol.16, Nairobi, Kenya: Gedion Were Press, pp.35-52.

Kilbride, P.L., 1990

Changing Family Life in Eastern Africa: Women and Children at Risk, Pennsylvania State

University Press (with J.E. Kilbride) (1993 reprinted Nairobi, Gedion Were Press).

KMMBS, 1994

Kenya Maternal Mortality Baseline Survey, PSRI, University of Nairobi, Nairobi.

Mboya, P., 1938

Luo Kitgi Gitimbegi, Nairobi: East African Publishing House.

Mukras, M.SC. and Oucho, J.O., 1985

Resource mobilization and the Household Economy in Kenya; in Canadian Journal of African

Studies, 19(2):401-21.

Obudho, R.A., 1981

Urbanization and Development Planning in Kenya,-Nairobi: Kenya Literature Bureau.

Obunga, A., 1987

Kinship Dependence in an Urban Setting: A Case Study of Buru Buru Estate, Nairobi. PSRI,

University of Nairobi.

Ocholla-Ayayo, 1997

The Implication of Our Creative Diversity in Global Ethics. Paper presented to workshop organised by UNESCO on Culture and Development for the 2lst Century, Nairobi: 24-25

February, 1997.

Ocholla-Ayayo, A.B.C, 1990

The Luo Culture: A Reconstruction of the Material Culture Patterns of an African Traditional

Society, Wiesbadan: Franzsteiner verlag GMBH.

Ocholla-Ayayo, A.B.C. 1986

"More children and the State of Childlessness: A Deterring Force Against Family Planning in

Kenya (ed) E. Ayiemba. Nairobi: PSRI, University of Nairobi.

Ocholla-Ayayo, A.B.C. 1996

Socio-Cultural Factors in Population and Development: From General Theories to Operational

Models. Paper to the 6th Conference of Pan-African Association of Anthropologists in

Pretoria, South Africa, from 9th-13th September, 1996.

Ocholla-Ayayo, A.B.C. and G.E.M. Ogutu 1996

The Impact of Religious and Socio-Cultural Values on Rural Transformation: Case Study of

Kano/Nyakach Districts in Kenya 1986-1987.

Ocholla-Ayayo, A.B.C. and Igbozurike, M., 1973

Leadership and the Masses in Africa South of Sahara: A Historical Approach to the Study of Underdevelopment; Unpublished Seminar Paper, S.D. Uppsala University, Doctoral Seminar, Oct., 1973.

Ocholla-Ayayo, A.B.C. and Ottieno, J.A.M., 1987

Socio-Cultural Codes of Fertility Differentials in Kenya, in E. Van de Walle and J.A. Ebigboh (eds) proceedings of the Ife Conference on the Determinants of African Fertility, Belgium (IUSSP). 
Ocholla-Ayayo, A.B.C. and Wekesa J.M. 1992

Population, Development and Land Carrying Capacity in Kenya. Proceedings of Conference on Population and Environment in Botswana, Southern Africa, September, 1992.

Ocholla-Ayayo, A.B.C., (1988b)

Polygyny and Family Planning in Kenya, in Khama Rogo (eds), A Manual of Clinical Family

Planning Practices, Ministry of Health, Nairobi: Kenya Medical Association.

Ocholla-Ayayo, A.B.C., 1970

Vyvoy doreka ajeho kulture ve vychonic Africe; M.Sc. thesis, Prague University.

Ocholla-Ayayo, A.B.C., 1976

Traditional Ideology and Ethics Among the Southern Luo, Uppsala: Scandinavian Institute of African Studies (SIAS).

Ocholla-Ayayo, A.B.C., 1981/82

Female Migration and Wealth Dissipation among the Patrilineal Exogamous Committee in

South Western Kenya, Research Report: Nairobi: PSRI, University of Nairobi.

Ocholla-Ayayo, A.B.C., 1985

Ethics, Customs and Population Control in Kenya; Working Paper No.5, Nairobi: PSRI,

University of Nairobi.

Ocholla-Ayayo, A.B.C., 1986

Culture and Society: Its Forms of Marriage and Reproduction. Moral Codes in Kenya;

Nairobi: PSRI, University of Nairobi.

Ocholla-Ayayo, A.B.C., 1987

Death and Burial: An Anthropological Perspective; in J.B. Ojwang and J.N.K. Mugambi (eds),

The S.M. Otieno Case: Death and Burial in Modern Kenya, Nairobi: Nairobi University Press.

Ocholla-Ayayo, A.B.C., 1988a

Marriage Patterns in Kenya and their Inter-relations with Fertility, in proceedings of African

Population Conference, Dakar: UAPS, Belgium, IUSSP.

Ocholla-Ayayo, A.B.C., 1989

Urban development without Planning: A Case Study of Migori town in Western Kenya, in

City of the Future, Vol.1, 7th Era Congress, Rotterdam.

Ocholla-Ayayo, A.B.C., 1990

The State of Childlessness in African Marriage: A Determining Force Against Family

Planning Efforts; in Elias H.O. Ayiemba (ed), Kenya Marriage in Transition, Population

Studies and Research Institute, U.O.N.

Ocholla-Ayayo, A.B.C., 1991

The Spirit of a Nation: An Analysis of Policy Ethics and Customary Rules of Conduct for

Regulating Fertility Levels in Kenya, Nairobi: Shirikon Publishers.

Ocholla-Ayayo, A.B.C., and Obunga, A., 1987

The Impact of Kinship ties in the Process of Urbanization in Kenya, in proceedings of

International Workshop at Uppsala: SIAS, 7-10 Sept., 1987.

Ocholla-Ayayo, A.B.C., and Ottieno, J.A.M, 1988

Anthropological Techniques for Demographic Field Studies in Kenya; in proceedings of

African Population Conference, Vol.3., Belgium: IUSSP.

Ojwang J.B., and Mugambi J.N.K. (ed) 1989

The S.M. Otieno Case: Death and Burial in Modern Kenya, Nairobi University Press, Nairobi.

Ominde, S.H., Ocholla-Ayayo, A.B.C., and Oyieng, J.C., 1983

Population Survey on Nutrition/Health and Family Planning of Peri-Urban Population of

Kisumu Municipality, Unpublished Report, Nairobi: PSRI, University of Nairobi.

Oppong C. and Abu K., 1987

Seven Roles of Women: Impact of Education, Migration and Employment on Ghanian

Mothers, Women, Work and Development Series, No.13, Geneva: ILO.

Oppong C., 1982

"Economic Models and having children: Some Evidence from Kwanu Ghana" in Africa, 52(3).

Oppong, C. (ed), 1983

Female and Male in Western Africa, London: George Ailen and Unwin. 
Oppong, C., 1991a

Relationships between Women's work and Demographic Behaviour: Some research evidence

in West Africa; ILO WEP 2-21 Working Paper No.175, Geneva: ILO.

Oppong, C., $1992 \mathrm{~b}$

Traditional Family Systems in Rural Setting in Africa; in E. Berquo and P. Xenos (eds).

Family Systems and Cultural Change, Oxford: Oxford University Press/Clarendon Press (for IUSSP).

Oppong, C., 1993

Socio-Economic Aspects of Sex Roles and Reproductive health; in Union for African Population Studies, Conference on Reproductive and Family Health in Africa 8-13 Nov, Dakar.

Oppong, C., 1994

African Family Systems in the Context of Socio-Economic Change, in UNECA Third African Population Conference: Conference papers, Addis Ababa.

Oppong, C., and Abu, K., 1987

Seven Roles of Women: Impact of Education, Migration and Employment on Ghanian Mothers, Women, Work and Development Series, No.13, Geneva: ILO.

Oucho, J.O. and Gould, W.T.S., 1993

"Internal Migration, Urbanization and Population Distribution", in Karen A. Foote, H., Hill and Linda, G. Martin (eds). Demographic Change in Sub-Saharan Africa, National Academic Press, Washington, D.C. pp.256-96.

Oucho, J.O., 1991

"Migration, Family Formation and Fertility: A Potent Research Area for Africa", Commissioned Paper, Conference on Women, Family and Population Vol. Dakar, UAPS.

Pospisil L., 1976

Anthropology of Law: A Comparative Theory, Harper \& Row Publishers, New York, Evanston, San Francisco, London.

Radcliffe-Brown, A.R. and Daryll Forde (eds), 1950

African Systems of Kinship and Marriage, London: Oxford University Press for International

African Institute.

Smelser, N.J. 1970

Industrialization and Society. Paris: UNESCO Press.

Smeiser, N.J., 1970

UN, 1965

Industrialization and Society, Paris, UNESCO Press.

UN, 1987

Universal Declaration of Human Rights, Article 21, New York: UN.

The Family: National Family Policies: Their Relationship to the Role of the Family in the Development Process (Vienna: Centre for Social Development and Humanitarian Affairs), New York: UN.

UNESCO 1956

Social Implications of Industrialization in Africa South of Sahara, Paris: UNESCO Press. UNESCO, 1956

Social Implications of Industrialization and Urbanization in Africa South of Sahara, Paris: UNESCO Press.

Weisner Th. S., Bradley. C., Kilbride Ph.l., 1997

African Families and the Crisis of Social Change, London: Bergin \& Garvey, Westport, Connecticut, London.

Weisner Thomas, 1976

The Structure of Sociability: Urban Migration and Urban-Rural ties in Kenya. Urban Anthropology, Vol.5. pp.199-223. 